\title{
Rare Presentation of a Rare Tumor: Histiocytic Sarcoma
}

\author{
Anil Kumar Reddy Reddivari ${ }^{1}$, Parth Mehta ${ }^{1,2}$, Usha Sree Janapala ${ }^{3}$ \\ 1. Internal Medicine, University of Illinois College of Medicine, Peoria, USA 2. Internal Medicine, Unity Point Health \\ Methodist Hospital, Peoria, USA 3. Neurology, University of Illinois College of Medicine, Peoria, USA
}

Corresponding author: Anil Kumar Reddy Reddivari, ranilreddy@gmail.com

\begin{abstract}
An 84-year-old male, with a large gouty tophus over the left elbow for 20 years, developed a new left elbow area mass about three months ago and presented to the emergency department (ED) with complaints of bleeding from that left elbow area mass after a small blunt injury. Initially diagnosed as olecranon bursitis, it had the worsening size and atypical growth associated with persistent leukocytosis. After being evaluated by multiple specialties, including infectious diseases, orthopedic surgery, and rheumatology, it was decided to do a biopsy, which resulted in the diagnosis of histiocytic sarcoma.
\end{abstract}

Categories: Dermatology, Internal Medicine, Oncology

Keywords: histiocytic, sarcoma, mass

\section{Introduction}

Histiocytic sarcoma is a very rare disease belonging to histiocytic disorders that originate from histiocytic cells that are of hematopoietic origin. Histiocytic sarcoma may occur as a sporadic extranodal neoplasm or may be a complication of hematologic malignancies such as follicular lymphoma or acute lymphoblastic leukemia. Histiocytic sarcoma (HS) is an aggressive neoplasm with a rapidly progressive course. With only a few hundred cases reported in the medical literature, HS contributes to less than $1 \%$ of all hematopoietic malignancies [1].

Clinical presentation is mostly a neoplastic mass, extranodal in location, commonly involving the skin. Other sites involved are the spleen and gastrointestinal tract. Associated signs and symptoms are nonspecific systemic symptoms such as fever, weight loss, anorexia, fatigue, hepatosplenomegaly, lymphadenopathy, rash, and pancytopenia. Diagnosis is made by the excisional or incisional biopsy of neoplastic tissue. Treatment options include local surgery, radiotherapy, and chemotherapy, depending on the stage of the disease. Being so rare, diagnosis is usually delayed and the overall prognosis of histiocytic sarcoma is very poor.

Received 02/04/2020 Review began 02/04/2020 Review ended 02/05/2020 Published 04/21/2020

\section{() Copyright 2020}

Reddivari et al. This is an open access article distributed under the terms of the Creative Commons Attribution License CC-BY 4.0., which permits unrestricted use, distribution, and reproduction in any medium, provided the original author and source are credited.
Here we submit a case report of a rare presentation of a very rare disease.

\section{Case Presentation}

An 84-year-old man with a past medical history of gouty arthritis, hypertension, chronic kidney disease stage III, cardiomyopathy, and atrial fibrillation presented to the emergency room with complaints of bleeding from the left elbow area. The patient had developed a mass about three months ago over the left elbow and was evaluated by his orthopedic surgeon, who diagnosed it as olecranon bursitis. Bleeding started after his elbow bumped into his car door. Vital signs at the time of presentation: blood pressure 99/60, pulse 100 per min, temperature $36.6^{\circ} \mathrm{C}$, respiratory rate 18 per min, and saturation $98 \%$.

Physical examination showed a soft tissue mass of about $6 \times 6 \mathrm{~cm}$ over the left elbow, just below the olecranon process, with a small area of skin necrosis and oozing of blood (Figure 1). The patient also had a large gouty tophus present for more than 20 years just proximal to the current mass (Figure 1). He was on chronic anticoagulation with coumadin for atrial fibrillation and found to have an elevated international normalized ratio (INR) of 3.0. 


\section{Cureus}

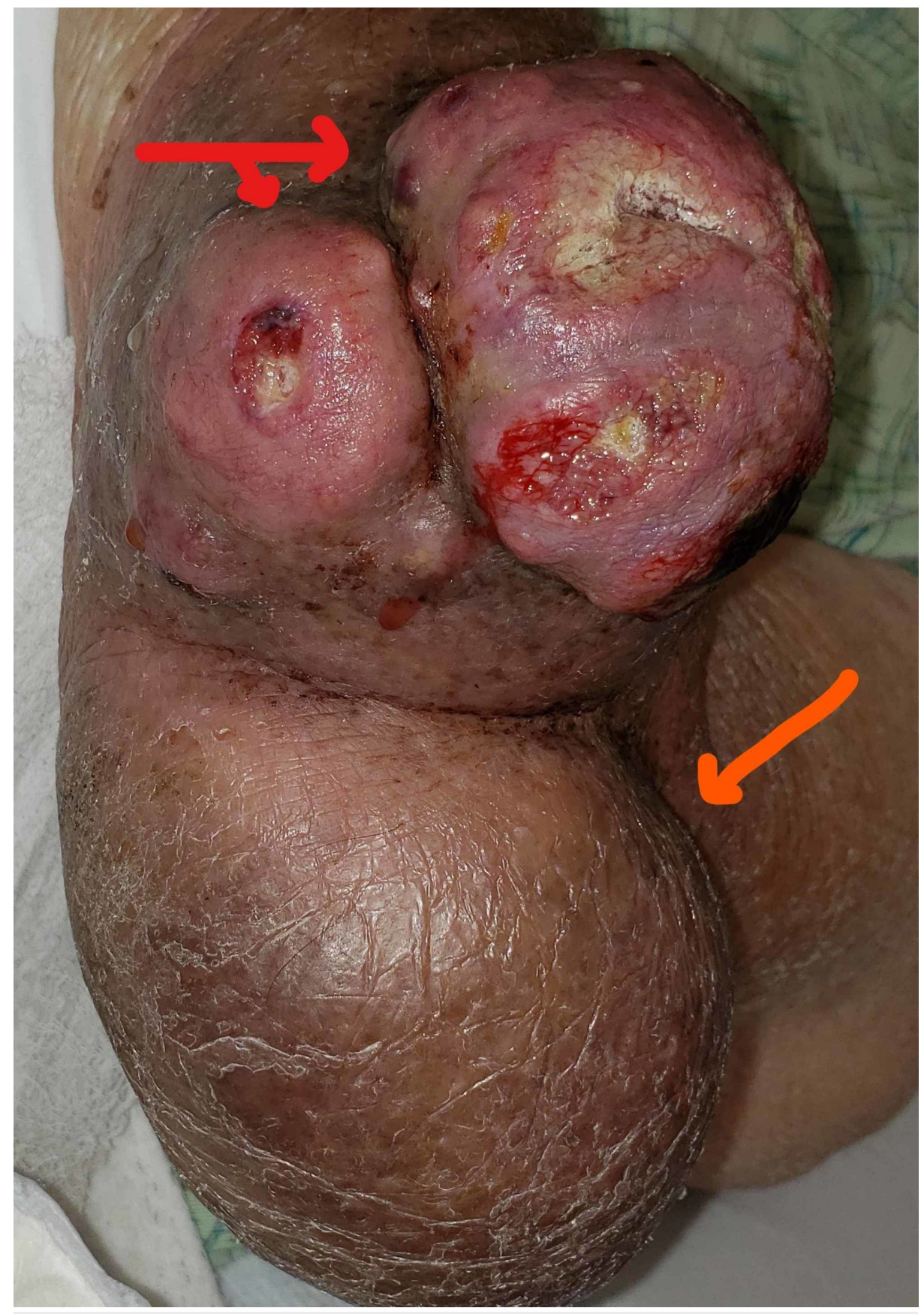

FIGURE 1: Two different masses over the left elbow

Red arrow - new mass; orange arrow - gouty tophus present for 20 years

The patient was admitted and treated for possible sepsis based on sepsis criteria. Coumadin was held and bleeding was stopped with a pressure dressing. Needle aspiration was done from the elbow mass with mild serosanguinous sterile fluid. Blood and fluid cultures were negative. Infectious diseases, orthopedic surgery, and rheumatology were consulted for the left elbow area mass. The patient had persistent leukocytosis (Table 1) even though he was clinically stable and the slowly growing mass for a couple of months raised suspicion for neoplastic disease. Dermatology was consulted, which did a bedside biopsy, with results favoring a histiocytic sarcoma (Figure 2). He underwent a bone marrow biopsy with no evidence of hemopoietic proliferative disorders. 


\section{Cureus}

\begin{tabular}{|c|c|c|c|c|c|c|c|c|c|c|c|c|c|c|c|c|c|c|c|c|}
\hline WBC & $\begin{array}{l}25.57 \\
\text { (H) }\end{array}$ & $\begin{array}{l}21.20 \\
\text { (H) }\end{array}$ & $\begin{array}{l}21.71 \\
\text { (H) }\end{array}$ & $\begin{array}{l}23.51 \\
\text { (H) }\end{array}$ & $\begin{array}{l}23.62 \\
\text { (H) }\end{array}$ & $\begin{array}{l}22.71 \\
\text { (H) }\end{array}$ & $\begin{array}{l}27.80 \\
\text { (H) }\end{array}$ & $\begin{array}{l}28.34 \\
\text { (H) }\end{array}$ & $\begin{array}{l}22.04 \\
\text { (H) }\end{array}$ & $\begin{array}{l}25.22 \\
\text { (H) }\end{array}$ & $\begin{array}{l}22.43 \\
\text { (H) }\end{array}$ & $\begin{array}{l}24.46 \\
\text { (H) }\end{array}$ & $\begin{array}{l}23.21 \\
\text { (H) }\end{array}$ & $\begin{array}{l}22.19 \\
\text { (H) }\end{array}$ & $\begin{array}{l}23.07 \\
\text { (H) }\end{array}$ & $\begin{array}{l}25.94 \\
\text { (H) }\end{array}$ & $\begin{array}{l}21.54 \\
\text { (H) }\end{array}$ & $\begin{array}{l}23.67 \\
\text { (H) }\end{array}$ & $\begin{array}{l}22.01 \\
\text { (H) }\end{array}$ & $\begin{array}{l}24.67 \\
\text { (H) }\end{array}$ \\
\hline Hemoglobin & $\begin{array}{l}11.5 \\
\text { (L) }\end{array}$ & $\begin{array}{l}10.3 \\
\text { (L) }\end{array}$ & $\begin{array}{l}10.9 \\
\text { (L) }\end{array}$ & $\begin{array}{l}11.0 \\
\text { (L) }\end{array}$ & $\begin{array}{l}11.3 \\
\text { (L) }\end{array}$ & $\begin{array}{l}10.9 \\
\text { (LL) }\end{array}$ & $\begin{array}{l}11.2 \\
\text { (LL) }\end{array}$ & $\begin{array}{l}11.0 \\
\text { (L) }\end{array}$ & $\begin{array}{l}10.1 \\
\text { (LL) }\end{array}$ & $\begin{array}{l}10.6 \\
\text { (ㄴ) }\end{array}$ & $\begin{array}{l}10.6 \\
\text { (L) }\end{array}$ & $\begin{array}{l}10.6 \\
\text { (L) }\end{array}$ & $\begin{array}{l}10.0 \\
\text { (LL) }\end{array}$ & $\begin{array}{l}10.2 \\
\text { (L) }\end{array}$ & $\begin{array}{l}10.4 \\
\text { (LL) }\end{array}$ & $\begin{array}{l}10.4 \\
\text { (L) }\end{array}$ & $\begin{array}{l}10.2 \\
\text { (L) }\end{array}$ & $\begin{array}{l}10.1 \\
\text { (LL) }\end{array}$ & $\begin{array}{l}10.1 \\
\text { (L) }\end{array}$ & $\begin{array}{l}10.2 \\
\text { (ㄴ) }\end{array}$ \\
\hline Hematocrit & $\begin{array}{l}37.7 \\
(L)\end{array}$ & $\begin{array}{l}33.5 \\
(L)\end{array}$ & $\begin{array}{l}35.2 \\
\text { (L) }\end{array}$ & $\begin{array}{l}34.9 \\
\text { (L) }\end{array}$ & $\begin{array}{l}36.5 \\
\text { (L) }\end{array}$ & $\begin{array}{l}35.7 \\
\text { (L) }\end{array}$ & 36.6 & $\begin{array}{l}36.5 \\
(L)\end{array}$ & $\begin{array}{l}33.4 \\
\text { (L) }\end{array}$ & $\begin{array}{l}34.6 \\
\text { (L) }\end{array}$ & 33.4 & $\begin{array}{l}34.7 \\
\text { (L) }\end{array}$ & $\begin{array}{l}33.5 \\
\text { (L) }\end{array}$ & 32.8 & 32.8 & $\begin{array}{l}33.3 \\
\text { (L) }\end{array}$ & 32.6 & $\begin{array}{l}32.8 \\
\text { (L) }\end{array}$ & $\begin{array}{l}32.7 \\
\text { (L) }\end{array}$ & $\begin{array}{l}31.8 \\
\text { (ㄴ) }\end{array}$ \\
\hline Platelets & 204 & 185 & 161 & 186 & 181 & 158 & 170 & 163 & 154 & 163 & 158 & 163 & 157 & 163 & 172 & 194 & 147 (L) & 169 & 164 & 171 \\
\hline
\end{tabular}

\section{TABLE 1: Persistent leukocytosis}

WBC: white blood cells

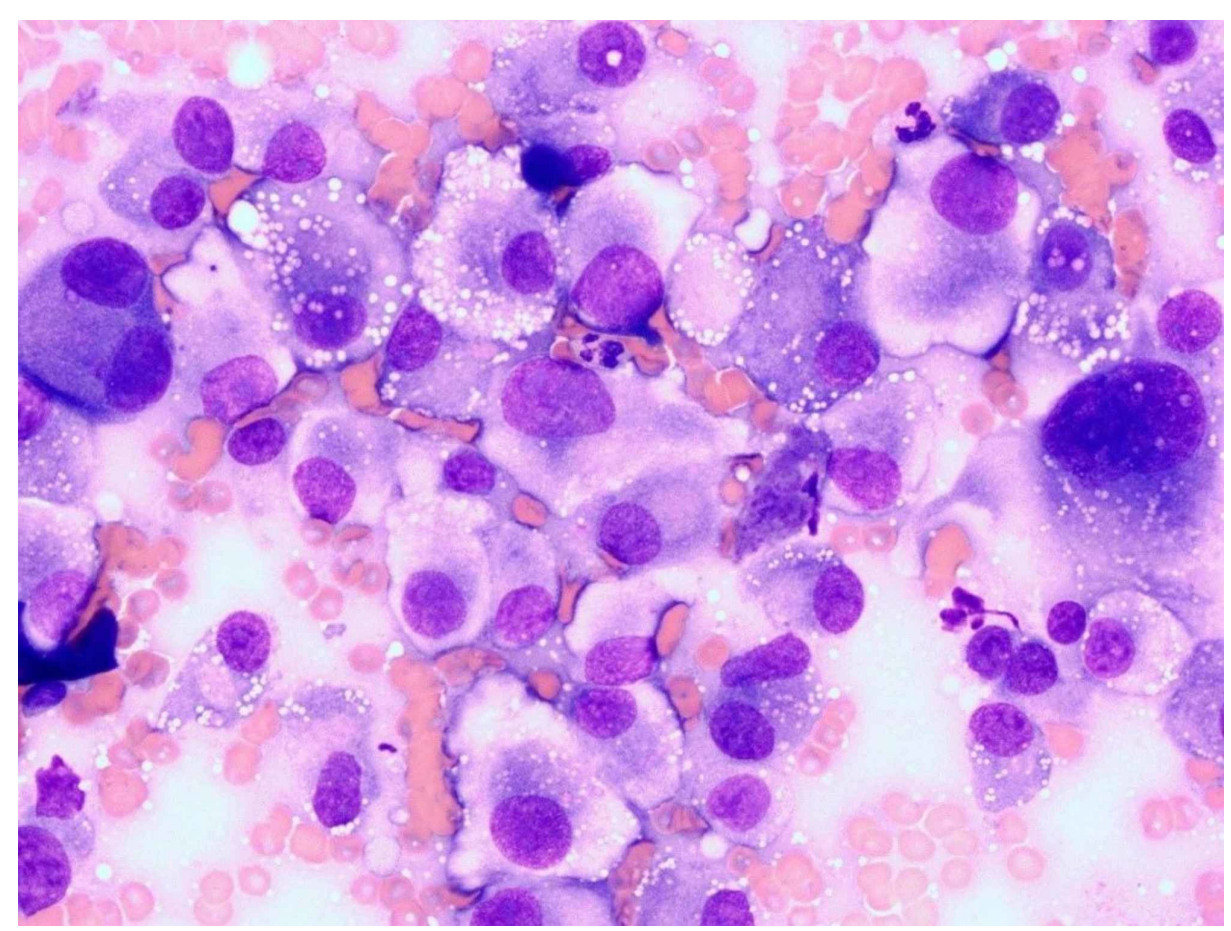

FIGURE 2: Atypical cells of histiocytic proliferation

Due to his advanced age with multiple comorbidities, including decompensated heart failure, along with worsening renal failure complicated by severe protein-calorie malnutrition and deconditioning, the patient became severely deconditioned with declining quality of life. Considering his overall prognosis, the patient and family together opted for comfort measures only and the patient passed away with hospice.

\section{Discussion}

Histiocytic sarcoma is a rare neoplasm of mature histiocytes, presents as a painless mass most commonly extranodal in origin, and can arise as a primary tumor or as a transformation of a pre-existing low-grade Bcell lymphoma. About $2 \%$ to $8 \%$ of chronic lymphocytic leukemia cases can transform into a histiocytic sarcoma [2]. Most cases were reported in adults with a slight male predominance [3].

The diagnosis of histiocytic sarcoma is made after an incisional/excisional biopsy based on the immunohistochemical delineation of the characteristic expression of one or more histiocytic markers. Specifically, the presence of macrophage-associated antigens, CD68, and lysozyme immunophenotypically confirm the histiocytic lineage. Also, CD163 has been recently characterized as a more specific marker for histiocytic neoplasms. In cases of histiocytic sarcoma arising from B-cell lymphomas, there may be a retention of some B-cell markers [4]. Typically, HS are negative for CD1a, CD21, and CD35, and they do not express B-cell, T-cell, or myeloid markers. The differential diagnosis includes other sarcomas such as rhabdomyosarcoma, Langerhans cell sarcoma, epithelioid sarcoma, and melanoma. Histologically, the tumor cells are usually large in size with abundant eosinophilic cytoplasm and eccentric round to oval nuclei. Small 
and distinct nucleoli with vesicular chromatin are present [2].

The standard of treatment is surgical with local resection. Adjuvant radiotherapy and chemotherapy are used especially for multifocal presentations. Bone marrow transplantation is an option depending on the presentation and immunophenotypes [5-6].

\section{Conclusions}

Histiocytic sarcoma is an aggressive tumor with about $50 \%$ mortality. It is a rare epithelioid malignancy often misdiagnosed with other sarcomas and cases of non-Hodgkins lymphoma. Histiocytic sarcoma may arise primarily as a soft tissue tumor and tumor size may be a prognostic factor. Hence, high clinical suspicion and vigilant pathological examination with specific immunohistochemical phenotyping are essential and play an important role in early diagnosis and, possibly, prognosis.

\section{Additional Information}

\section{Disclosures}

Human subjects: Consent was obtained by all participants in this study. Conflicts of interest: In compliance with the ICMJE uniform disclosure form, all authors declare the following: Payment/services info: All authors have declared that no financial support was received from any organization for the submitted work. Financial relationships: All authors have declared that they have no financial relationships at present or within the previous three years with any organizations that might have an interest in the submitted work. Other relationships: All authors have declared that there are no other relationships or activities that could appear to have influenced the submitted work.

\section{References}

1. Machado ES, de Miranda AC, Escopelli T, Caron R, Escopelli AC: Histiocytic sarcoma. Rev Bras Hematol Hemoter. 2011, 33:155-157.

2. Skala SL, Lucas DR, Dewar R: Histiocytic sarcoma: review, discussion of transformation from B-cell lymphoma, and differential diagnosis. Arch Pathol Lab Med. 2018, 142:1322-1329. 10.5858/arpa.2018-0220RA

3. Vos JA, Abbondanzo SL, Barekman CL, Andriko JW, Miettinen M, Aguilera NS: Histiocytic sarcoma: a study of five cases including the histiocyte marker CD163. Mod Pathol. 2005, 18:693-704. 10.1038/modpathol.3800346

4. Ali Z, Hanif F: Unusual presentation of a rare tumor: histiocytic sarcoma presenting as a finger growth . Cureus. 2019, 11:e6150. 10.7759/cureus.6150

5. Gergis U, Dax H, Ritchie E, Marcus R, Wissa U, Orazi A: Autologous hematopoietic stem-cell transplantation in combination with thalidomide as treatment for histiocytic sarcoma: a case report and review of the literature. J Clin Oncol. 2011, 1:251-253.

6. Pellitteri PK, Ferlito A, Bradley PJ, Shaha AR, Rinaldo A: Management of sarcomas of the head and neck in adults. Oral Oncol. 2003, 39:2-12. 10.1016/s1368-8375(02)00032-5 